\title{
Faktor-faktor yang memengaruhi pernikahan usia dini di Indonesia
}

\section{Factors affecting early marriage in Indonesia}

\author{
Adinda Hermambang*, Choirul Ummah, Eunike Sola Gratia, Fathul Sanusi, \\ Wilda Maria Ulfa, Rani Nooraeni \\ Politeknik Statistika STIS \\ *Korespondensi penulis: adindahermambang@gmail.com
}

\begin{abstract}
One of the social problems that existed in Indonesia is high rates of early marriage or child marriage. Based on its absolute number, Indonesian has been one of top ten country with the highest number of child marriage all over the world. Early marriage is defined as a marital union by women under 16 years old. Many factors affect early marriage, such as education factor, economy factor, and culture factor. Furthermore, early marriage may have effects on deteriorating physical and psychological health, low educational attainment, and increasing risk of domestic violence. By utilising 2017 IDHS dataset, this study aims to examine the determinants of early marriage in Indonesia. This study applies binary logistic regression method for the data analysis. The results of this study show that variables significantly affect the status of early marriage are marital status at the first sexual intercourse, residential type, partner's working status, women's education, and partner's education. Moreover, variables that do not significantly affect the status of early marriage are women's working status, wealth index, and interaction between women's education and wealth index.
\end{abstract}

Keyword: early marriage, binary logistic regression, IDHS

\begin{abstract}
ABSTRAK
Salah satu permasalahan sosial yang ada di Indonesia adalah tingginya angka pernikahan dini atau perkawinan anak. Secara absolut, Indonesia tergolong dalam 10 negara dengan angka perkawinan anak tertinggi di dunia. Pernikahan dini didefinisikan sebagai pernikahan yang dilakukan oleh perempuan yang berusia di bawah 16 tahun. Pernikahan dini dapat disebabkan oleh berbagai faktor seperti pendidikan, ekonomi, dan budaya. Lebih jauh lagi, fenomena pernikahan dini dapat berpengaruh terhadap penurunan kesehatan fisik dan psikologis, capaian pendidikan yang rendah, dan risiko terjadinya kekerasan domestik. Dengan menggunakan data SDKI 2017, kajian ini bertujuan untuk mengetahui faktor-faktor yang mempengaruhi pernikahan dini di Indonesia. Metode yang digunakan pada penelitian ini adalah analisis regresi logistik biner. Hasil penelitian ini menunjukkan bahwa variabel-variabel yang berpengaruh secara signifikan terhadap pernikahan dini di Indonesia adalah status pernikahan saat berhubungan seksual pertama kali, tipe tempat tinggal, status bekerja pasangan, pendidikan wanita, dan pendidikan pasangan. Sementara itu, variabel-variabel yang tidak berpengaruh signifikan adalah status bekerja wanita, indeks kekayaan, dan interaksi antara pendidikan wanita dan indeks kekayaan.
\end{abstract}

Kata Kunci: pernikahan dini, regresi logistik biner, SDKI

\section{PENDAHULUAN}

Menurut Undang-Undang No. 1 Tahun 1974, perkawinan atau pernikahan adalah ikatan lahir batin antara seorang pria dan wanita sebagai suami istri dengan tujuan membentuk keluarga (rumah tangga) yang bahagia dan kekal berdasarkan Ketuhanan yang Maha Esa. Pernikahan merupakan sesuatu yang sakral yang dilakukan untuk mencapai tujuan tertentu seperti melanjutkan keturunan, meningkatkan derajat dan status sosial, mendekatkan kembali hubungan kekerabatan yang renggang, atau bahkan untuk menjaga agar harta tidak jatuh ke pihak lain. Di 
Indonesia, angka perkawinan selalu meningkat dari tahun ke tahun. Pada tahun 2017 terdapat 1.936.934 penduduk yang melakukan perkawinan dan jumlahnya meningkat hingga 2.016.171 penduduk pada tahun 2018 (BPS dkk., 2020).

Sebagaimana telah diatur oleh UndangUndang No. 1 Tahun 1974, perkawinan diizinkan jika wanita telah mencapai 16 tahun dan 19 tahun untuk pria. Sementara itu, Badan Kependudukan dan Keluarga Berencana Nasional (BKKBN) menyatakan bahwa umur ideal seseorang melakukan perkawinan pertama adalah 21 tahun untuk wanita dan 25 tahun untuk pria dengan pertimbangan matangnya kondisi biologis dan psikologis seseorang pada umur tersebut. Pada kenyataannya, masih banyak masyarakat Indonesia yang menikah di bawah aturan usia yang ditetapkan. Situasi ini menandakan terjadinya pernikahan dini/perkawinan anak.

Mereka yang digolongkan pernikahan dini adalah perempuan yang menikah pertama di usia 16 tahun atau kurang (BPS dkk., 2020). Proporsi pernikahan dini di Indonesia meningkat menjadi $15,7 \%$ pada 2018 dibanding tahun sebelumnya sebesar 14,2\%. UNICEF (2020) juga mencatat bahwa perempuan umur 20-24 tahun di Indonesia yang menikah sebelum berusia 18 tahun mencapai 1.220 .900 pada tahun 2018. Angka ini menjadikan Indonesia berada pada posisi 10 besar negara dengan angka absolut perkawinan anak tertinggi di dunia.

Meningkatnya pernikahan dini dapat menjadi sebuah permasalahan kependudukan. Hal ini dikarenakan pernikahan dini membawa banyak dampak negatif pada berbagai aspek kehidupan. Pada aspek pendidikan, anak yang melakukan perkawinan dini umumnya akan berhenti melanjutkan pendidikannya. Pernikahan dini seringkali menimbulkan siklus kemiskinan yang baru. UNICEF Global Database (2020) bahkan mencatat bahwa pernikahan dini akan merugikan setidaknya $1,7 \%$ pendapatan nasional suatu negara. Selain itu, pernikahan dini lebih rentan mengalami kekerasan dalam rumah tangga, perselingkuhan, dan perceraian akibat kurang matangnya psikologis anak. Di sisi lain, pernikahan dini akan membahayakan kesehatan calon ibu karena anatomi tubuh anak belum siap untuk proses mengandung dan melahirkan, dan kehamilan dapat mengakibatkan komplikasi pada tubuh. Bayi yang lahir dari perkawinan usia dini pun 1,5 kali lebih rentan meninggal selama 28 hari pertama.

Dampak yang ditimbulkan dari pernikahan dini dapat dicermati di berbagai dimensi kehidupan sehingga perlu diketahui faktor-faktor penyebabnya. Hal ini perlu dilakukan untuk mencegah kenaikan angka kejadian pernikahan dini. Pohan (2017) menyebutkan faktor-faktor yang berhubungan dengan pernikahan usia dini terhadap remaja putri antara lain pendidikan, pengetahuan, pekerjaan, status ekonomi, budaya, pergaulan bebas, dan media massa. Selanjutnya, Widyawati dan Pierewan (2017) menyatakan bahwa tingkat pendidikan, tingkat pendapatan, dan religiusitas menjadi determinan pernikahan usia dini di Indonesia. Pernikahan dini juga terbukti dipengaruhi oleh pendapatan orang tua, kepercayaan orang tua, budaya, dan teman sebaya (Wijayati dkk., 2017). Selain itu, penyebab utama pernikahan anak dapat berupa kemiskinan, kendala pendidikan dan ekonomi, tradisi, serta agama (Judiasih dkk., 2018). Kajian Muntamah dkk. (2019) turut mengemukakan bahwa faktorfaktor penyebab pernikahan dini adalah ekonomi, pendidikan yang rendah, keinginan sendiri, pergaulan bebas dan adat istiadat.

Status melakukan hubungan seks pertama kali bisa terjadi sebelum atau sesudah nikah. Melakukan hubungan seks sebelum nikah banyak terjadi pada kalangan muda. Hasil penelitian oleh Kasim (2014) di Aceh menunjukkan Kota Lhokseumawe memiliki angka $70 \%$ keterlibatan pelajar melakukan hubungan seks sebelum nikah. Salah satu dampak dalam penelitian itu adalah kasus kehamilan yang tidak diinginkan. Menurut Pusdatin Kementerian Kesehatan (2015), remaja yang aktif melakukan seks sebelum nikah akan berdampak pada kehamilan yang tidak direncanakan sehingga akan berlanjut pada aborsi dan pernikahan dini. 
Di daerah perdesaan, pernikahan dini umumnya masih dianggap hal yang biasa, terutama daerah perdesaan yang masih menjalankan adat atau budaya yang mendukung terjadinya pernikahan dini. Di daerah-daerah tersebut umumnya masih terdapat perjodohan oleh orang tua, ditambah dengan letak geografis yang sulit dan akses pendidikan yang minim menjadikan banyak terdapat pernikahan dini. Penelitian oleh Widyawati dan Pierewan (2017) menunjukkan bahwa area tempat tinggal di perdesaan 1,6\% lebih tinggi untuk melakukan pernikahan usia dini dibandingkan dengan area tempat tinggal di perkotaan.

Pendidikan rendah dan pekerjaan yang menghasilkan pendapatan rendah juga dapat menyebabkan anak dinikahkan dalam usia muda. Anak yang menikah pada usia muda bisa mengurangi beban orang tua. Menurut Wijayati dkk. (2017), orang tua dengan pendapatan kecil akan meningkatkan kejadian pernikahan dan faktor ekonomi menjadi penghalang untuk menyekolahkan anaknya ke jenjang lebih tinggi.

Status pekerjaan bagi laki-laki sangat penting sebelum menjalin pernikahan. Laki-laki yang sudah bekerja tentu lebih siap untuk menikah daripada yang belum bekerja. Berbeda dengan perempuan yang memilih menikah daripada menganggur, status pekerjaan dalam pernikahan dini cenderung terjadi pada perempuan yang tidak bekerja. Hasil ini sesuai dengan penelitian yang dilakukan oleh Pohan (2017) yang menunjukkan bahwa remaja putri yang tidak bekerja memiliki kecenderungan 4,2 kali lebih besar untuk melakukan pernikahan dini dibandingkan remaja putri yang bekerja.

Berdasarkan latar belakang tersebut, peneliti tertarik untuk melakukan penelitian mengenai faktor-faktor yang memengaruhi pernikahan usia dini di Indonesia. Kajian ini bertujuan untuk mengetahui gambaran pernikahan dini di Indonesia secara keseluruhan serta menganalisis faktorfaktor apa saja yang memengaruhi pernikahan dini di Indonesia.
Penelitian menggunakan data Survei Demografi dan Kesehatan Indonesia (SDKI) tahun 2017. Responden adalah wanita usia subur (WUS) atau wanita yang berusia 15-49 tahun. Pernikahan dini pada penelitian ini merujuk pada pernikahan yang dilakukan oleh seorang wanita berumur 16 tahun ke bawah. Sesuai dengan data yang tersedia dalam SDKI 2017, faktor-faktor yang dianalisis meliputi status melakukan hubungan seks pertama kali, tipe tempat tinggal, status bekerja wanita dan pasangan, indeks kekayaan, dan pendidikan wanita dan pasangan. Penelitian dilakukan dengan menerapkan metode regresi logistik biner. Hasil dari kajian ini diharapkan dapat menjadi bahan evaluasi maupun perencanaan bagi pemerintah untuk menekan angka pernikahan dini di Indonesia.

\section{METODOLOGI PENELITIAN}

Penelitian ini menggunakan pendekatan jenis kuantitatif kausal yang bertujuan untuk mengetahui pengaruh dari satu variabel terhadap variabel lain. Ruang lingkup penelitian mencakup seluruh Indonesia. Data yang digunakan berupa data mentah Survei Demografi dan Kesehatan Indonesia tahun 2017 yang diselenggarakan oleh BPS bekerja sama dengan BKKBN dan Kementerian Kesehatan. Unit analisis yang digunakan adalah wanita usia subur (WUS). Jumlah WUS yang memenuhi kriteria sebagai unit analisis, yaitu WUS yang berstatus kawin sebelum umur 16 tahun adalah 32.661 responden.

Metode analisis yang digunakan adalah analisis inferensia. Analisis inferensia digunakan untuk mengetahui pengaruh variabel-variabel yang ada terhadap pernikahan dini di Indonesia. Untuk mencapai tujuan tersebut maka digunakan analisis regresi logistik biner.

\section{Regresi logistik biner}

Regresi logistik biner merupakan metode yang digunakan untuk menganalisis hubungan antara variabel dependen $(\mathrm{Y})$ yang bersifat biner dan variabel independen (X). Variabel dependen dan independent pada penelitian ini dapat dicermati pada Tabel 1. 
Tabel 1. Variabel dependen dan variabel independen

\begin{tabular}{|c|c|c|}
\hline Variabel & Kategori & Dummy \\
\hline \multicolumn{3}{|l|}{ Status pernikahan dini } \\
\hline Tidak menikah dini & 0 & \\
\hline Menikah dini & 1 & $\mathrm{Y}$ \\
\hline \multicolumn{3}{|c|}{ Melakukan hubungan seks pertama kali } \\
\hline $\begin{array}{l}\text { Hubungan seks pertama kali } \\
\text { sesudah menikah }\end{array}$ & 0 & \\
\hline $\begin{array}{l}\text { Hubungan seks pertama kali } \\
\text { sebelum menikah }\end{array}$ & 1 & $\mathrm{X}_{1}$ \\
\hline \multicolumn{3}{|l|}{ Tipe tempat tinggal } \\
\hline Kota & 0 & \\
\hline Desa & 1 & $\mathrm{X}_{2}$ \\
\hline \multicolumn{3}{|l|}{ Status bekerja wanita } \\
\hline Bekerja & 0 & \\
\hline Tidak bekerja & 1 & $\mathrm{X}_{3}$ \\
\hline \multicolumn{3}{|l|}{ Status bekerja pasangan } \\
\hline Bekerja & 0 & \\
\hline Tidak bekerja & 1 & $\mathrm{X}_{4}$ \\
\hline \multicolumn{3}{|l|}{ Indeks kekayaan } \\
\hline Sangat kaya & 0 & \\
\hline Kaya & 1 & $\mathrm{X}_{51}$ \\
\hline Menengah & 2 & $\mathrm{X}_{52}$ \\
\hline Miskin & 3 & $\mathrm{X}_{53}$ \\
\hline Sangat miskin & 4 & $\mathrm{X}_{54}$ \\
\hline \multicolumn{3}{|l|}{ Pendidikan wanita } \\
\hline$>=$ SMA & 0 & \\
\hline SMP & 1 & $\mathrm{X}_{61}$ \\
\hline SD & 2 & $\mathrm{X}_{62}$ \\
\hline Tidak pernah bersekolah & 3 & $\mathrm{X}_{63}$ \\
\hline \multicolumn{3}{|l|}{ Pendidikan pasangan } \\
\hline$>=$ SMA & 0 & \\
\hline SMP & 1 & $\mathrm{X}_{71}$ \\
\hline SD & 2 & $\mathrm{X}_{72}$ \\
\hline Tidak pernah bersekolah & 3 & $\mathrm{X}_{73}$ \\
\hline
\end{tabular}

Ketika variabel Y dalam kondisi demikian, maka variabel Y mengikuti distribusi Bernoulli untuk setiap observasi tunggal. Fungsi probabilitas untuk setiap observasi adalah sebagai berikut:

$$
f\left(y_{i}\right)=\pi_{i}^{y_{i}}\left(1-\pi_{i}\right)^{\left(1-\pi_{i}\right)} ; y_{i}=0,1
$$

\section{Keterangan:}

$\pi_{\mathrm{i}}$ adalah peluang kejadian ke-I

$y_{i}$ adalah peubah acak ke-i

Model regresi logistiknya adalah sebagai berikut:

$$
\pi\left(x_{i}\right)=\frac{\exp \left(\beta_{0}+\beta_{1} x_{1 i}+\ldots+\beta_{p} X_{p i}\right)}{1+\exp \left(\beta_{0}+\beta_{1} x_{1 i}+\ldots+\beta_{p} X_{p i}\right)}
$$

\section{Keterangan:}

$\mathrm{p}$ adalah banyaknya variabel prediktor

Model transformasi logit dari $\pi(x)$ dari persamaan di atas dapat dituliskan sebagai berikut:

$$
\ln \frac{\pi(x)}{1-\pi(x)}=\beta_{0}+\beta_{1} x_{1 i}+\ldots+\beta_{p} X_{p i}
$$

\section{Uji simultan}

Uji simultan dilakukan untuk mengetahui signifikansi parameter terhadap variabel respon secara keseluruhan. Uji ini menggunakan Omnibus Tests of Model Coefficients. Hipotesis yang diuji adalah:

$\mathrm{H} 0: \beta 1=\beta 2=\ldots=\beta \rho=0$

H1: paling sedikit ada satu $\beta i \neq 0$, dengan $\mathrm{i}=1,2, \ldots, \mathrm{p}$ 
Statistik uji:

$$
G=-2 \ln \frac{L_{0}}{L_{1}}
$$

Keterangan:

Lo adalah likelihood tanpa variabel independen

L1 adalah likelihood dengan variabel independen

Daerah penolakan : tolak Ho jika $\mathrm{G}>x^{2}(v, \alpha)$ $; v$ merupakan jumlah variabel independen.

\section{Uji parsial}

Hasil pengujian secara individual akan menunjukkan apakah suatu variabel prediktor (x) layak untuk masuk dalam model atau tidak. Hipotesis yang digunakan adalah:

$$
\begin{aligned}
& \mathrm{H} 0: \beta j=0 \\
& \mathrm{H} 1: \beta j \neq 0 \text {; dengan } \mathrm{j}=1,2,3, \ldots, \mathrm{p}
\end{aligned}
$$

Statistik uji: Uji Wald $W=\frac{\widehat{\beta}}{S E \widehat{\beta} J} \quad$; tolak
H0 jika $|W|>Z_{\alpha / 2}$

\section{Uji Kesesuaian Model}

Uji kesesuaian model digunakan untuk mengetahui apakah ada perbedaan yang signifikan antara hasil pengamatan dengan kemungkinan hasil prediksi model. Berikut adalah hipotesis yang digunakan:

\section{H0: Model sesuai}

H1: Model tidak sesuai

Statistik Uji:

$$
\hat{C}=\sum_{k=1}^{g} \frac{\left(0_{k}-n_{k}^{\prime} \bar{\pi}_{k}\right)^{2}}{n_{k}^{\prime} \bar{\pi}_{k}\left(1-\bar{\pi}_{k}\right)}
$$

Keterangan:

$$
O_{k} \text { adalah observasi pada grup ke-k }
$$

$n_{k}^{\prime}$ adalah jumlah observasi dalam grup ke-k

$\bar{\pi}_{k}$ adalah rata-rata taksiran peluang

g adalah jumlah kombinasi kategori dalam model serentak

Data yang digunakan dalam kajian ini merupakan data mentah dari sebuah survei. Oleh karena itu, perlu dilakukan data cleaning terlebih dahulu sebelum melakukan analisis inferensia. Data cleaning dilakukan dengan cara penghapusan missing value dan jawaban "tidak tahu". Hal ini dilakukan karena missing data dapat menyebabkan hasil observasi tidak dapat dianalisis dengan baik (Hendrawati, 2015).

\section{HASIL DAN PEMBAHASAN}

\section{Gambaran Pernikahan Dini di Indonesia}

Hasil penelitian menunjukkan bahwa wanita usia subur yang melakukan pernikahan dini atau umur perkawinan pertamanya kurang dari 17 tahun di Indonesia sebanyak 17,53\%. Dilansir UNICEF Global Database (2020), wanita usia subur di negara ASEAN yang menikah di bawah umur 15 tahun sebesar $8 \%$ dan yang menikah di bawah umur 18 tahun sebesar 29\%. Oleh karena itu, angka pernikahan dini di Indonesia dapat dikatakan cukup tinggi.

Berdasarkan Tabel 2 dapat disimpulkan bahwa secara keseluruhan, pernikahan dini pada wanita usia subur terjadi di setiap kategori untuk masing-masing variabel. Dari data yang diperoleh, proporsi pernikahan dini pada WUS yang melakukan hubungan seksual pertama sebelum menikah lebih banyak daripada yang melakukan hubungan seksual pertama sesudah menikah. WUS yang berhubungan seksual sebelum menikah mempunyai risiko tinggi untuk mengalami kehamilan yang 
tidak diinginkan. Hastuti dan Aini (2016) dalam penelitiannya menemukan responden yang terpaksa menikah dini karena positif hamil walaupun masih muda dan tidak memahami dampaknya. Sunaryanto (2019) juga menyatakan bahwa dalam pandangan orang tua, satu-satunya solusi kehamilan sebelum pernikahan adalah menikahkan anak, bukan dengan menggugurkan janin karena perbuatan tersebut merupakan perbuatan dosa besar.

Kedua, untuk variabel tipe tempat tinggal, proporsi pernikahan dini pada WUS yang bertempat tinggal di desa lebih banyak daripada yang bertempat tinggal di kota. Hal ini disebabkan oleh perbedaan pola pikir dan cara pandang orang yang tinggal di desa dan kota. Di perkotaan, seseorang lebih memilih untuk mengejar kesuksesan karir atau pendidikan terlebih dahulu sebelum memutuskan untuk menikah. Berbeda dengan seseorang yang tinggal di perdesaan yang umumnya mempunyai tingkat pendidikannya cenderung lebih rendah dan masih terdapat tradisi yang masih menjadi patokan dalam menentukan keputusan menikah (Sahara dkk., 2018).

Ketiga, jika dilihat dari variabel status bekerja WUS maupun pasangannya, proporsi pernikahan dini pada WUS dan pasangannya yang tidak bekerja lebih banyak dibandingkan dengan yang bekerja. Mambaya dan Stang (2011) mengemukakan bahwa seseorang yang tidak berpendapatan akan memiliki ketergantungan yang lebih besar kepada orang lain daripada seseorang

Tabel 2. Persentase pernikahan dini WUS berdasarkan karakteristik individu

\begin{tabular}{|c|c|c|c|}
\hline Variabel & Kategori & Tidak & Ya \\
\hline \multirow{4}{*}{$\begin{array}{l}\text { Melakukan hubungan seks } \\
\text { pertama kali }\end{array}$} & Berhungan seks pertama & 18,26 & 81,74 \\
\hline & kali sesudah menikah & & \\
\hline & Berhungan seks pertama & 91,67 & 8,33 \\
\hline & kali sebelum menikah & & \\
\hline \multirow{2}{*}{ Tipe tempat tinggal } & Kota & 87,71 & 12,29 \\
\hline & Desa & 76,86 & 23,14 \\
\hline \multirow{2}{*}{ Status bekerja wanita } & Bekerja & 82,98 & 17,02 \\
\hline & Tidak bekerja & 81,79 & 18,21 \\
\hline \multirow{2}{*}{ Status bekerja pasangan } & Bekerja & 82,56 & 17,44 \\
\hline & Tidak bekerja & 76,42 & 23,58 \\
\hline \multirow{5}{*}{ Indeks kekayaan } & Sangat kaya & 92,45 & 7,55 \\
\hline & Kaya & 85,74 & 14,26 \\
\hline & Menengah & 82,05 & 17,95 \\
\hline & Miskin & 77,47 & 22,53 \\
\hline & Sangat miskin & 75,09 & 24,91 \\
\hline \multirow{4}{*}{ Pendidikan wanita } & $>=$ SMA & 98,99 & 1,01 \\
\hline & SMP & 87,95 & 12,05 \\
\hline & $\mathrm{SD}$ & 67,08 & 32,92 \\
\hline & Tidak pernah bersekolah & 54,69 & 45,31 \\
\hline \multirow{4}{*}{ Pendidikan pasangan } & $>=$ SMA & 95,63 & 4,37 \\
\hline & SMP & 86,67 & 13,33 \\
\hline & SD & 70,12 & 29,88 \\
\hline & Tidak pernah bersekolah & 60,63 & 39,37 \\
\hline
\end{tabular}

Sumber: Olah data SDKI 2017 
yang memiliki pendapatan sendiri. Oleh sebab itu, mereka yang tidak bekerja akan mencari pasangan yang dapat membiayai hidupnya. WUS dan pasangannya yang tidak bekerja biasanya melakukan pernikahan dini karena faktor perjodohan atau faktor saling mencintai antar pasangan sehingga melakukan pernikahan tanpa memperhatikan status pekerjaan.

Jika dilihat dari indeks kekayaan, proporsi pernikahan dini WUS yang paling tinggi adalah WUS yang berstatus sangat miskin, kemudian diikuti oleh WUS yang berstatus miskin, WUS yang berstatus menengah, dan WUS yang berstatus kaya. Proporsi pernikahan dini yang paling rendah dimiliki oleh WUS yang berstatus sangat kaya. Kemungkinan hal ini terjadi karena faktor ekonomi yang dilihat adalah faktor ekonomi dari orang tua WUS. Stigma di masyarakat menganggap bahwa pernikahan dini dapat menjadi solusi untuk meringankan beban keluarga miskin dan mengangkat derajat keluarga tersebut. Hal ini sejalan dengan apa yang dikatakan oleh Wulandari (2014) dalam penelitiannya yang menemukan bahwa terdapat nilai yang berkembang di masyarakat bahwa anak perempuan merupakan aset ekonomi keluarga yang dapat mengangkat derajat ekonomi keluarga.

Dari data yang ada, pendidikan WUS maupun pendidikan pasangan mempunyai hubungan yang negatif dengan kasus pernikahan dini. Semakin tinggi pendidikan WUS dan pendidikan pasangan, maka proporsi WUS yang menikah dini akan lebih sedikit. Hal ini dapat terjadi karena semakin tinggi pendidikan yang ditempuh, semakin banyak paparan pengetahuan tentang dampak pernikahan dini yang didapat oleh WUS dan pasangannya. Mereka yang menempuh pendidikan tinggi juga akan lebih memikirkan untuk menyelesaikan pendidikan daripada memikirkan pernikahan. Status pendidikan ini sebenarnya dapat berkaitan dengan status ekonomi WUS. WUS yang berstatus ekonomi miskin tidak mempunyai kemampuan finansial untuk melanjutkan sekolah ke jenjang yang lebih tinggi. Mereka terpaksa putus sekolah karena alasan ekonomi keluarga dan memilih menikah dini untuk menghindari hal-hal yang tidak diharapkan dan agar dapat meringankan beban keluarga (Wulandari, 2014).

\section{FAKTOR-FAKTOR YANG MEMENGARUHI PERNIKAHAN DINI DI INDONESIA}

Hasil uji simultan pada tabel Omnibus Tests of Model Coefficients menunjukkan nilai $p$ value $(0,000)<0,05$ yang menandakan tingkat signifikansi 5\% di Indonesia pada tahun 2017. Selanjutnya, untuk uji parsial, digunakan uji statistik Wald. Nilai statistik uji Wald dibandingkan dengan nilai $(3,84)$ atau $p$-value dibandingkan dengan $\alpha=0,05$. Jika nilai $p$-value $<0,05$ maka keputusan adalah tolak $\mathrm{H}_{0}$ yang berarti variabel independen tersebut berpengaruh secara signifikan terhadap status pernikahan dini. Berdasarkan hasil pengolahan dengan tingkat signifikansi 5\%, variabel-variabel yang berpengaruh signifikan terhadap status pernikahan dini adalah status pernikahan saat melakukan hubungan seksual pertama kali, tempat tinggal, pendidikan wanita, pendidikan pria, dan status kerja pria. Sementara itu, variabel kekayaan, status kerja wanita, dan interaksi antara kekayaan dan pendidikan wanita tidak berpengaruh signifikan terhadap status pernikahan dini. Model yang terbentuk dapat dilihat pada Tabel 3. Uji kecocokan model (Goodness of Fit) menggunakan uji Hosmer and Lemeshow. Pada tabel diperoleh $p$-value $(0,193)>0,05$ maka keputusan yang diambil adalah gagal tolak $\mathrm{H}_{0}$. Hal ini menunjukkan bahwa model tersebut telah fit atau cocok untuk digunakan.

\section{Melakukan hubungan seks pertama kali}

Hasil p-value menunjukkan signifikansi 0,000 yang berarti variabel status pernikahan saat melakukan seks pertama kali berpengaruh signifikan terhadap perilaku menikah dini pada wanita. Nilai Odds ratio (OR) yang ditunjukkan dengan Exp(B) menunjukkan kecenderungan bahwa wanita yang melakukan hubungan seks setelah menikah 0,365 kali berisiko untuk menikah dini dibandingkan dengan wanita yang melakukan hubungan seks sebelum menikah. Hal ini sejalan dengan hasil penelitian Pohan (2017) yang menyatakan bahwa pergaulan bebas berpengaruh terhadap pernikahan dini. Selain itu, banyak pasangan yang terpaksa menikah dini akibat pihak perempuan hamil sebelum menikah (Hastuti \& Aini, 2016). Biasanya pergaulan bebas ini diawali 
Tabel 3. Ringkasan hasil regresi logistik biner

\begin{tabular}{|c|c|c|c|c|c|c|c|}
\hline Variabel & Dummy & B & S.E & Wald & Df & Sig & $\operatorname{Exp}(B)$ \\
\hline \multicolumn{8}{|l|}{ Berhubungan seks pertama kali } \\
\hline \multicolumn{8}{|l|}{ Sesudah menikah } \\
\hline Sebelum menikah & $\mathrm{X}_{1}$ & $-1,007$ & 0,078 & 168,645 & 1 & 0,000 & 0,365 \\
\hline \multicolumn{8}{|l|}{ Tipe tempat tinggal } \\
\hline \multicolumn{8}{|l|}{ Kota } \\
\hline Desa & $\mathrm{X}_{2}$ & 0,354 & 0,036 & 99,616 & 1 & 0,000 & 1,425 \\
\hline \multicolumn{8}{|l|}{ Status bekerja wanita } \\
\hline \multicolumn{8}{|l|}{ Bekerja } \\
\hline Tidak bekerja & $\mathrm{X}_{3}$ & 0,009 & 0,031 & 0,091 & 1 & 0,763 & 1,010 \\
\hline \multicolumn{8}{|l|}{ Status bekerja pasangan } \\
\hline \multicolumn{8}{|l|}{ Bekerja } \\
\hline Tidak bekerja & $\mathrm{X}_{4}$ & 0,434 & 0,122 & 12,639 & 1 & 0,000 & 1,543 \\
\hline \multicolumn{8}{|l|}{ Indeks kekayaan } \\
\hline \multicolumn{8}{|l|}{ Sangat kaya } \\
\hline Kaya & $\mathrm{X}_{51}$ & 0,350 & 0,380 & 0,848 & 1 & 0,357 & 1,419 \\
\hline Menengah & $\mathrm{X}_{52}$ & 0,163 & 0,478 & 0,116 & 1 & 0,734 & 1,177 \\
\hline Miskin & $\mathrm{X}_{53}$ & 0,901 & 0,404 & 4,981 & 1 & 0,026 & 2,462 \\
\hline Sangat miskin & $\mathrm{X}_{54}$ & 0,351 & 0,561 & 0,392 & 1 & 0,532 & 1,420 \\
\hline \multicolumn{8}{|l|}{ Pendidikan wanita } \\
\hline \multicolumn{8}{|l|}{$>=$ SMA } \\
\hline SMP & $X_{61}$ & 2,357 & 0,255 & 85,160 & 1 & 0,000 & 10,561 \\
\hline $\mathrm{SD}$ & $X_{62}$ & 3,914 & 0,266 & 217,334 & 1 & 0,000 & 50,105 \\
\hline Tidak pernah bersekolah & $X_{63}$ & 4,548 & 0,662 & 47,226 & 1 & 0,000 & 94,418 \\
\hline \multicolumn{8}{|l|}{ Pendidikan pasangan } \\
\hline \multicolumn{8}{|l|}{$>=$ SMA } \\
\hline SMP & $\mathrm{X}_{71}$ & 0,375 & 0,089 & 17,583 & 1 & 0,000 & 1,455 \\
\hline $\mathrm{SD}$ & $\mathrm{X}_{72}$ & 0,792 & 0,092 & 73,931 & 1 & 0,000 & 2,208 \\
\hline Tidak pernah bersekolah & $X_{73}$ & 0,971 & 0,129 & 56,363 & 1 & 0,000 & 2,641 \\
\hline \multicolumn{8}{|l|}{ Indeks kekayaan * pendidikan wanita } \\
\hline Kaya * SMP & $\mathrm{X}_{811}$ & $-0,330$ & 0,389 & 0,722 & 1 & 0,396 & 0,719 \\
\hline Kaya $*$ SD & $\mathrm{X}_{812}$ & $-0,512$ & 0,395 & 1,678 & 1 & 0,195 & 0,600 \\
\hline Kaya $*$ tidak pernah bersekolah & $\mathrm{X}_{813}$ & $-0,363$ & 0,814 & 0,199 & 1 & 0,656 & 0,696 \\
\hline Menengah * SMP & $\mathrm{X}_{821}$ & 0,039 & 0,485 & 0,006 & 1 & 0,936 & 1,039 \\
\hline Menengah * SD & $\mathrm{X}_{822}$ & $-0,403$ & 0,489 & 0,680 & 1 & 0,410 & 0,668 \\
\hline Menengah $*$ tidak pernah bersekolah & $\mathrm{X}_{823}$ & $-0,268$ & 0,821 & 0,106 & 1 & 0,744 & 0,765 \\
\hline Miskin * SMP & $\mathrm{X}_{831}$ & $-0,549$ & 0,411 & 1,782 & 1 & 0,182 & 0,578 \\
\hline Miskin * SD & $\mathrm{X}_{832}$ & $-1,128$ & 0,416 & 7,370 & 1 & 0,007 & 0,324 \\
\hline Miskin $*$ tidak pernah bersekolah & $\mathrm{X}_{833}$ & $-1,310$ & 0,756 & 2,998 & 1 & 0,083 & 0,270 \\
\hline Sangat miskin $*$ SMP & $\mathrm{X}_{841}$ & 0,135 & 0,566 & 0,057 & 1 & 0,812 & 1,144 \\
\hline Sangat miskin $*$ SD & $\mathrm{X}_{842}$ & $-0,840$ & 0,569 & 2,179 & 1 & 0,140 & 0,432 \\
\hline Sangat Miskin * tidak pernah bersekolah & $\mathrm{X}_{843}$ & $-1,087$ & 0,836 & 1,690 & 1 & 0,194 & 0,337 \\
\hline Konstanta & & $-5,152$ & 0,246 & 438,443 & 1 & 0,000 & 0,006 \\
\hline
\end{tabular}

Sumber: Olah data SDKI 2017 
dengan berpacaran yang kemudian berlanjut pada melakukan hubungan seksual di luar pernikahan. Dampak dari hubungan seksual ini adalah banyak wanita usia dini yang menikah karena hamil di luar nikah akibat pergaulan bebas tersebut. Hal ini didukung juga dengan berkembangnya media sosial yang sangat pesat sehingga seseorang dapat mengakses konten-konten yang berhubungan dengan perilaku hubungan sosial dengan mudah.

\section{Tipe tempat tinggal}

Hasil penelitian menunjukkan bahwa tipe tempat tinggal berpengaruh secara signifikan terhadap pernikahan dini. Wanita yang tinggal di daerah pedesaan memiliki kecenderungan untuk menikah dini sebesar 1,425 kali dibandingkan wanita yang tinggal di daerah perkotaan dengan asumsi variabel lain konstan. Hal ini sesuai dengan temuan dari Mitiku dkk. (2018) yang mengemukakan bahwa tipe tempat tinggal berpengaruh secara signifikan terhadap pernikahan dini. Soekarno (2011) turut menyatakan bahwa rata-rata umur kawin pertama lebih rendah di wilayah pedesaan dibandingkan perkotaan. Umur kawin di perkotaan yang tinggi kemungkinan berhubungan dengan kesibukan masyarakat kota untuk melanjutkan pendidikan ke jenjang yang lebih tinggi di usia muda sehingga mereka yang tinggal di perkotaan lebih fokus pada karir daripada menikah.

\section{Status bekerja wanita}

Berdasarkan hasil uji Chi-square dengan nilai p-value 0,763 , terlihat bahwa tidak terdapat perbedaan yang signifikan antara perempuan yang belum bekerja dan perempuan yang sudah bekerja dalam hal kecenderungan melakukan pernikahan dini. Pernyataan ini diperkuat dengan hasil analisis deskriptif yang menunjukkan adanya kecenderungan perempuan yang sudah bekerja untuk melakukan pernikahan dini 1,1 kali lebih besar dibandingkan perempuan yang belum bekerja. Hal ini menunjukkan bahwa status bekerja wanita tidak berpengaruh terhadap pernikahan dini karena pada umumnya masyarakat menganggap bahwa mencari nafkah adalah tugas seorang laki-laki dan perempuan tidak diwajibkan untuk bekerja. Menurut Notoatmojo (2003), pekerjaan merupakan bagian dari faktor sosial yang bersifat dinamis yang memberikan pengaruh yang berbeda pada tiap individu. Artinya, tidak ada perbedaan pengaruh yang didapat oleh remaja yang bekerja maupun yang tidak bekerja. Selain itu, kajian Yunita (2014) menunjukkan bahwa faktor yang memengaruhi pernikahan usia dini adalah pekerjaan orang tua karena pekerjaan orang tua menentukan keadaan ekonomi sebuah keluarga. Namun, faktor tersebut tidak dimasukkan dalam penelitian kali ini.

\section{Status bekerja pasangan}

Hasil uji Chi-square dengan nilai p-value yang sangat kecil dan kurang dari 0,05 menunjukkan adanya perbedaan yang signifikan antara wanita yang calon pasangannya sudah bekerja dan wanita yang calon pasangannya belum bekerja dalam hal kecenderungan melakukan pernikahan dini. Wanita yang calon pasangannya bekerja memiliki kecenderungan 1,543 kali lebih besar untuk melakukan pernikahan dini dibandingkan wanita yang calon suaminya belum bekerja. Hal ini melengkapi pernyataan sebelumnya pada hubungan status bekerja wanita dengan pernikahan dini bahwa anggapan masyarakat yang bahwa mencari nafkah adalah tugas laki-laki. Laki-laki yang sudah bekerja dan memiliki penghasilan dianggap mampu memberi nafkah dan bertanggung jawab terhadap kelangsungan hidup rumah tangga. Hasil penelitian ini sejalan dengan penelitian yang dilakukan oleh Syafangah dan Luluk (2017) yang menyatakan kecenderungan wanita yang calon pasangannya sudah bekerja untuk melakukan pernikahan dini adalah 2,824 kali lebih besar dibandingkan dengan wanita yang pasangannya belum bekerja.

\section{Indeks kekayaan}

Indeks kekayaan merupakan indeks yang menyatakan karakteristik latar belakang rumah tangga yang digunakan untuk mengukur standar hidup suatu rumah tangga dalam jangka panjang. Indeks kekayaan diukur melalui beberapa indikator karakteristik perumahan dan kepemilikan barang, jenis sumber air minum, fasilitas toilet, dan karakteristik lainnya yang terkait dengan status sosial ekonomi suatu rumah tangga. Dalam publikasi hasil SDKI 2017, terdapat 5 kategori indeks 
kekayaan yaitu sangat kaya sebagai kategori referensi, kaya, menengah, miskin, dan sangat miskin. Pada empat kategori non-referensi tersebut, hanya satu kategori yang signifikan, yaitu kategori miskin terhadap sangat kaya dengan signifikansi 0.026. Nilai OR menunjukkan bahwa wanita dengan indeks kekayaan miskin 2,462 lebih cenderung untuk menikah dini dibanding wanita dengan indeks kekayaan sangat kaya. Pohan (2017) mengemukakan bahwa status ekonomi berpengaruh terhadap perilaku menikah dini. Hal ini memungkinkan karena semakin tinggi tingkat kekayaan seseorang, maka semakin tinggi pula tingkat pendidikannya sehingga akan cenderung lebih fokus kepada karir. Penelitian Yunita (2014) juga menunjukkan bahwa sebuah keluarga yang berada di garis kemiskinan memiliki kecenderungan untuk menikahkan anak perempuannya dengan orang yang lebih mampu dengan anggapan hal tersebut dapat meringankan beban keluarga.

\section{Pendidikan wanita}

Hasil penelitian menunjukkan bahwa wanita yang berpendidikan SMP memiliki kecenderungan untuk menikah dini sebesar 10,561 kali dibandingkan wanita yang berpendidikan minimal SMA. Sementara itu, wanita yang berpendidikan SD memiliki kecenderungan untuk menikah dini sebesar 50,105 kali dibandingkan wanita yang berpendidikan minimal SMA. Wanita yang tidak pernah bersekolah memiliki kecenderungan untuk menikah dini sebesar 94,418 kali dibandingkan wanita yang berpendidikan minimal SMA. Hasil ini sesuai dengan hasil penelitian yang dilakukan oleh Widyawati dan Pierewan (2017) yang menyatakan bahwa pendidikan berpengaruh secara signifikan terhadap pernikahan dini di Indonesia.

Muntamah dkk. (2019) menyatakan bahwa faktor pendidikan yang rendah adalah yang sangat mempengaruhi pola pemikiran suatu masyarakat, baik dari pendidikan orang tua maupun si anak sendiri. Wanita yang berpendidikan tinggi cenderung terlibat dalam pasar kerja dan memilih untuk meniti karir sehingga mengurangi peluang melakukan pernikahan usia dini. Pada wanita yang tidak bekerja namun memutuskan untuk menikah, maka umur saat menikah sudah melebihi batas usia menikah yang ditetapkan oleh UU Perkawinan di Indonesia. Sementara itu, masyarakat yang berpendidikan rendah biasanya tergolong masyarakat dengan tingkat ekonomi yang rendah sehingga menikahkan anak perempuannya dianggap dapat mengurangi beban ekonomi keluarga.

\section{Pendidikan pasangan}

Hasil penelitian menunjukkan bahwa wanita yang pasangannya berpendidikan SMP memiliki kecenderungan untuk menikah dini sebesar 1,455 kali dibandingkan wanita yang pasangannya berpendidikan minimal SMA. Sementara itu, wanita yang pasangannya berpendidikan SD memiliki kecenderungan untuk menikah dini sebesar 2,208 kali dibandingkan wanita yang pasangannya berpendidikan minimal SMA. Sedangkan wanita yang pasangannya tidak pernah bersekolah memiliki kecenderungan untuk menikah dini sebesar 2,641 kali dibandingkan wanita yang pasangannya berpendidikan minimal SMA.

Adanya hubungan antara pendidikan pasangan dan pernikahan dini diperkuat dengan beberapa hasil penelitian lain. Misalnya, penelitian Widyawati dan Pierewan (2017) yang menyatakan bahwa pendidikan pasangan menjadi salah satu faktor penentu pernikahan dini. Pendidikan pasangan yang rendah mempunyai risiko yang lebih besar dalam melakukan pernikahan dini. Penelitian lainnya oleh Ma'mun (2015) juga menunjukkan bahwa pendidikan pasangan berpengaruh terhadap terjadinya pernikahan dini. Pasangan yang memiliki status pendidikan dasar dan menengah cenderung melakukan pernikahan dini dibandingkan pasangan yang mengenyam pendidikan tinggi.

\section{Interaksi antara indeks kekayaan dan pendidikan wanita}

Indeks kekayaan diukur berdasarkan beberapa indikator sosial ekonomi dalam suatu rumah tangga. Indeks kekayaan juga dapat menggambarkan tingkat ekonomi suatu rumah tangga. Tingkat ekonomi ini yang mendukung seseorang untuk mendapatkan pendidikan hingga mencapai tingkat tertentu. Dalam penelitian ini, 
peneliti juga mengamati adanya interaksi antara indeks kekayaan dan pendidikan wanita untuk mengetahui pengaruh indeks kekayaan yang didasarkan pada tingkat pendidikan wanita terhadap status pernikahan dini. Berdasarkan hasil uji Chi-square, tidak terdapat pengaruh yang signifikan dari indeks kekayaan berdasarkan pendidikan wanita terhadap kecenderungan pernikahan dini. Pengujian menghasilkan nilai $p$-value $>0,05$ yang menunjukkan bahwa tidak terdapat perbedaan yang berarti pada indeks kekayaan berdasarkan pendidikan wanita terhadap kecenderungan melakukan pernikahan dini. Artinya, interaksi antara indeks kekayaan dengan pendidikan wanita tidak memiliki pengaruh yang berarti terhadap pernikahan dini. Indeks kekayaan dan pendidikan wanita berpengaruh pada kecenderungan melakukan pernikahan dini saat dihitung secara parsial tanpa interaksi.

\section{KESIMPULAN}

Angka perkawinan dini di Indonesia masih tinggi. Secara umum, perkawinan dini terjadi pada wanita usia subur yang tinggal di desa, tidak bekerja, berstatus sangat miskin, tidak bersekolah, pasangan tidak bekerja dan pasangan tidak sekolah. Hasil penelitian analisis logistik biner menunjukkan variabel-variabel yang berpengaruh signifikan terhadap status pernikahan dini pada wanita usia subur adalah status pernikahan melakukan seks pertama kali, tempat tinggal, pendidikan, pendidikan pasangan, dan status kerja pasangan. Tingkat perekonomian di pedesaan yang lebih rendah dibandingkan perkotaan menjadikan masyarakat cenderung mengenyam pendidikan yang rendah karena ketiadaan biaya. Status bekerja pasangan yang berpengaruh signifikan juga menunjukkan bahwa dengan menikahkan anak perempuannya maka beban ekonomi untuk menghidupi anak perempuan tersebut akan berpindah kepada suaminya yang bekerja. Hal ini mendorong terjadinya pernikahan dini karena menikahkan anak perempuan dengan orang yang lebih mampu akan dianggap mengurangi beban ekonomi keluarga dibandingkan membiayainya untuk melanjutkan pendidikan.

Saran yang dapat diberikan adalah perlunya peningkatan sosialisasi mengenai faktor-faktor penyebab pernikahan dini sehingga dapat mengurangi terjadinya pernikahan dini. Dari sisi pemerintah, program pemerintah mengenai wajib belajar 9 (sembilan) tahun perlu dievaluasi dan ditingkatkan. Penyediaan fasilitas dan kemudahan akses pendidikan juga perlu ditingkatkan agar untuk mendukung program wajib belajar tersebut agar dapat menjangkau seluruh lapisan masyarakat. Pemerintah juga hendaknya terus aktif menggerakkan perekonomian sehingga dapat meningkatkan kesejahteraan masyarakat, utamanya di wilayah pedesaan. Selain itu, sosialisasi mengenai pendidikan seksual hendaknya lebih gencar dilakukan sehingga remaja mendapatkan pengetahuan seksual sedini mungkin untuk menghindari terjadinya hubungan seksual saat usia dini. Dari sisi masyarakat, remaja pria maupun wanita disarankan mengikuti kegiatan positif seperti mengikuti kursus atau les agar bisa memiliki keterampilan sehingga lebih mudah mencari pekerjaan apabila tidak dapat melanjutkan ke jenjang pendidikan tinggi. Demikian pula bagi orang tua hendaknya lebih berperan aktif untuk mengawasi pergaulan anaknya agar tidak terjadi seks sebelum menikah.

\section{DAFTAR PUSTAKA}

BPS, USKAPA UI, \& UNICEF (2020). Pencegahan perkawinan anak: Percepatan yang tidak bisa ditunda. Bappenas, KemenPPPA, \& UNICEF. https://puskapa.org/publikasi/881/

Hastuti, P., \& Aini, F. N. (2016). Gambaran terjadinya pernikahan dini akibat pergaulan bebas. Jurnal Riset Kesehatan, 5(1), 11-13. https://doi. org/10.31983/jrk.v5i1.444

Hendrawati, T. (2015). Kajian metode imputasi dalam menangani missing data. Prosiding Seminar Nasional Matematika dan Penddikan Matematika UMS 2015 (637-642). http://hdl.handle. net/11617/5804

Judiasih, S. D., Suparto, S., Afriana, A., \& Yuanitasar, D. (2018). Women, law, and policy: Child marriage practice in Indonesia. Jurnal Notariil, 3(1), 47-55. https://doi.org/10.22225/ jn.3.1.647.47-55

Kasim, F. (2014). Dampak perilaku seks berisiko terhadap kesehatan reproduksi dan upaya penanganannya: Studi tentang perilaku seks berisiko pada usia muda di Aceh. Jurnal Studi Pemuda, 3(1), 39-48. https://doi.org/10.22146/ studipemudaugm.32037 
Pusdatin Kementerian Kesehatan. (2015). Situasi kesehatan reproduksi remaja. Kementerian Kesehatan Republik Indonesia. https://pusdatin.kemkes.go.id/article/view/15090700003/ situasi-kesehatan-reproduksi-remaja.html

Ma'mun, M. S. (2015). Faktor pendorong pernikahan dini di Kabupaten Banyuwangi [Skripsi, Universitas Negeri Jember]. http://repository.unej. ac.id/handle/123456789/65989

Mambaya, E., \& Stang, S. (2011). Faktor yang berhubungan dengan pernikahan dini di Kelurahan Pangli Kecamatan Sesean Kabupaten Toraja Utara. Media Kesehatan Masyarakat Indonesia Universitas Hasanuddin, 7(2), 105-110.

Mitiku, Y., Kiffle, D., Siyoum, D., \& Birlie, B. (2018). Determinants of time to first marriage among rural women in Ethiopia. Biomedical Statistics and Informatics, 3(1). https://doi. org/10.11648/j.bsi.20180301.11

Muntamah, A. L., Latifiani, D., \& Arifin, R. (2019). Pernikahan dini di Indonesia: Faktor dan peran pemerintah (Perspektif penegakan dan perlindungan hukum bagi anak). Widya Yuridika Jurnal Hukum, 2(1), 1-12. https://doi. org/10.31328/wy.v2i1.823

Notoatmojo, S. (2003). Ilmu kesehatan masyarakat. Rineka Cipta.

Pohan, N. H. (2017). Faktor yang berhubungan dengan pernikahan usia dini terhadap remaja putri. Jurnal Endurance, 2, 424-435. http:// doi.org/10.22216/jen.v2i3.2283

Sahara, N., Idris, I., \& Putri, D. Z. (2018). Faktor-faktor yang mempengaruhi keputusan wanita menikah di Sumatera Barat. Jurnal Ecogen, 1(3), 640-647. http://dx.doi.org/10.24036/jmpe. v1i3.5110

Soekarno. (2011). Pengaruh faktor sosial ekonomi terhadap fertilitas dan umur kawin pertama. Jurnal Ilmiah Puslitbang KB dan KS, 5(1), 9-15.
Sunaryanto, H. (2019). Analisis sosial-ekonomi faktor penyebab perkawinan anak di Bengkulu: Dalam perspektif masyarakat dan pemerintah (Studi kasus di Kabupaten Seluma). Jurnal Sosiologi Nusantara, 5(1), 22-42. https://doi. org/10.33369/jsn.5.1.22-42

Syafangah, U., \& Luluk, R. (2017). Hubungan tingkat pendidikan dan pekerjaan dengan pernikahan dini pada remaja putri di Kecamatan Gamping Kabupaten Sleman tahun 2016. http://digilib2.unisayogya.ac.id/xmlui/ handle/123456789/1844

UNICEF (2020). Child marriage in Indonesia. BPS Support UNICEF.

UNICEF Global Database. (2020). Child marriage. https://data.unicef.org/topic/child-protection/ child-marriage/

Widyawati, E., \& Pierewan, A. C. (2017). Determinan pernikahan usia dini di Indonesia. Jurnal Ilmu-Ilmu Sosial, 14(4), 55-70. https://doi. org/10.21831/socia.v14i1.15890

Wijayati, N. A., Soemanto, R. B., \& Pamungkasari, E. P. (2017). Socioeconomic and cultural determinants of early marriage in Ngawi, East Java: Application of precede-proceed model. Journal of Health Promotion and Behaviour, 2(4), 302-312. https://doi.org/10.26911/thejhpb.2016.02.04.02

Wulandari, D. A. (2014). Komitmen pada perkawinan ditinjau dari kepuasan dalam perkawinan. Prosiding Seminar Hasil Penelitian LPPM UMP 2014 (161-165). https://docplayer. info/45194929-Komitmen-pada-perkawinanditinjau-dari-kepuasan-dalam-perkawinan.html

Yunita, A. (2014). Faktor-faktor yang berhubungan dengan kejadian pernikahan usia muda pada remaja putri di Desa Pagerejo Kabupaten Wonosobo. STIKES Ngudi Waluyo. 